\title{
License Plate Recognition Integrated with Android and Mobile Vision
}

\author{
Muhammad Rizky Adinugroho \\ Software Engineering Technology, \\ Agriculture Polytechnic of \\ Samarinda, 75242, Indonesia \\ rizkyadi245@gmail.com
}

\author{
Eko Junirianto \\ Software Engineering Technology, \\ Agriculture Polytechnic of \\ Samarinda, 75242, Indonesia \\ eko@politanisamarinda.ac.id
}

\author{
Annafi Franz* \\ Software Engineering Technology, \\ Agriculture Polytechnic of \\ Samarinda, 75242, Indonesia \\ annafifranz@gmail.com \\ *Corresponding Author
}

Received: 2021-07-28; Revised: 2021-08-14; Accepted: 2021-08-17; Published: 2021-09-01

\begin{abstract}
License plate is an important thing on vehicle. License plate is an identity of vehicle. All of the information about type, year, tax, and owner of vehicle. The development of technology especially in digital image processing and mobile android technology. There are so many android applications that used digital image processing known as optical character recognition. The purpose of this paper is to make an android application that can recognize license plate with mobile vision library. The research method of this paper is waterfall, starts with integrating android with mobile vision library and doing test to find out the accuracy of mobile vision. Designing an application models with flowchart diagram and unified modeling language.
\end{abstract}

Keywords - License plate, android, mobile vision, optical character recognition, vehicle, technology

\section{INTRODUCTION}

License plate is an important thing for vehicle to operate on the road. It is an identity of the vehicle that operate on the road, so it was put on the front side and rear side of the vehicle. It is must be easy to seen by people or police. Based on statistic data from East Borneo, total vehicle in East Borneo is 2.376.033 unit registered. Mostly from Samarinda City that reach 683.420 vehicle registered. This number is show that there are a lot of vehicle, so the facilities and infrastructure must be good.

One of the most important facilities is parking facilities. Parking facilities is really important for market area, department store area, office area, or campus area. Parking facilities will manage the vehicle who visits that area. Because of that, good parking management is needed to make people feel safe and comfort when park their vehicle.

On parking facilities there is a person who manage the vehicle in parking area. This person will give parking ticket to people who parked there for paying the parking services. This ticket contains information about license plate and price the people must pay. This person still doing this in conventional way, so the data record of vehicle who was parked is still write by hand and this is not good.
With rapid development in technology and high mobility, this problem can be solved by using an application for the person who manages parking area.

Because of high mobility is needed, so this application will be android application and using android studio to build it. This modern parking application will make the person who manage parking area easy to record the data of vehicle who was used the parking service. There is one feature that can extract the license plate of vehicle become text just 2 taps on screen. With this feature recording data will be easier and faster. Algorithm that used to extract the license plate is Optical Character Recognition (OCR).

Based on above description of the background can be formulated existing problems such as how to implementing mobile vision library to android how to know the accuracy of mobile vision. The purpose of this paper is to implement the mobile vision library and integrate it in android application using android studio. The objectives and expected result of this implementation is to know the accuracy of mobile vision.

\section{LITERATURE REVIEW}

\section{A. Study of Literature}

Some of the literature as a guide and reference in this paper:

1. Research conducted by Kusumawati \& Cahyadi ( 2017) with the title Implementation of Optical Character Recognition to Detect License plate of Vehicle. License Plate Recognition (LPR) is one of the making use of digital image processing to detect license plate of vehicle which is use to recording data automatically into the parking system.

2. Research conducted by Mardiansyah (2017) with the title Utilization of Library Open CV and Tesseract to Recognizing Car License plate in Indonesia. To recognize license plate, require digital image input that contain object number. In Indonesia Optical Character Recognition is still on development specially to recognizing license plate of vehicle. In another country the OCR has developed to recognize license plate, but it could not be used just like that because there are some differences license plate format. 
3. Research conducted by Mansyur (2018) with the title Optical Character Recognition to Recognizing Car and Motorcycle License plate in Gowa University. There are lot of technic or algorithm to convert digital image that contain text into file text and one of the algorithm is Optical Character Recognition. This function of algorithm is scan the digital image and convert it into file text. With this algorithm the image that contain handwriting or text can be recognized.

4. Research conducted by Utama \& Kusumawardhani (2018) with the title Application Indonesia License plate Recognizer Using Open CV and Tesseract on Android Studio. Digital image processing on license plate is an innovation to make easy recording data and secure the vehicle. In Indonesia recording data of license plate is still manual. There are so many research about recognizing license plate system. System of recognizing license plate consist of 2 steps character segmentation and character recognition. Different country make different algorithm in recognizing license plate, because of differences the type of license plate.

5. Research conducted by Ibnutama et al (2019) with the title Modification Template Matching Method in OCR to Increase Accuracy of Recognizing License plate. Template Matching is one of the algorithm that can be implemented on OCR to recognizing character from digital image. But, the accuration of recognizing result is depend on quality of digital image like noise, etc. The digital image that has bad quality can reduce the accuration and increasing the percentage false when recognizing.

\section{B. Optical Character Recognition}

Optical Character Recognition (OCR) is an computer application that used to recognizing alphabet or number character in digital image and convert it into text file. This system can increase the flexibility or ability and intelligence of computer system. This system is very helpful for big company that run business in information and knowledge digitalization, like collection of digital library, collection of ancient literature, etc. (Hartanto et al, 2015).

OCR is effective solution to convert printed document into digital document. There is a step of OCR process.

1. File input

Digital image with format. bpm or .jpg

2. Preprocessing

The process to erase the part that not use in digital image.

3. Segmentation

The process to separate area over the recognized character.

4. Normalization

The process to change region dimension and bold of every character.

5. Extraction

The process to gain characteristic from character.

\section{Recognition}

The process to recognize character with comparing characteristic of the character with characteristic data in database.

\section{Mobile Vision API}

Mobile Vision API is a framework developed by Google. This framework is implemented for object detection or extracting data from digital image, video, or picture from smartphone camera (Ming, 2018).

There are 3 feature of Mobile Vision, Face API, Barcode API, and Text Recognition API.

1. Face API

The algorithm to recognize human face in photos or video automatically.

2. Barcode API

The algorithm to detect barcode using camera on smartphone.

3. Text Recognition API

The algorithm to recognize text that contain on photos, images, videos and convert it into file text.

\section{Android}

Android is an operating system that developed for linux based mobile hardware. This operating system start developing by Android Inc. then bought by Google in 2005 and in 2007 Open Handset Alliance is made in purpose to develop the mobile hardware system (Maiyana, 2018).

\section{E. Android Studio}

Android Studio is Integrated Development Environment (IDE) for developing android application, based on Intellij IDEA. Android studio giving so much feature to increase productivity when make an android application. Android studio is developed based on Intellij IDEA which is similar with Eclipse along with Android Development Tools (ADT) plugin.

\section{F. Java}

In computer science, Java is a programming language that object oriented and introduced on 1995 by Sun Microsystem. At first, programming language java is called Oak. Java as programming language that have their own syntax and programming rules. Java as platform where this technology has virtual machine and library that needed for build and run the program. Java is born because developer want to use programming language that not bound with any platform, so this is make java is portable (Maiyana, 2018).

\section{G. Android Software Development Kit (SDK)}

Android software development kit is API tools that required to start developing application on android platform using programming language java. Android SDK is consist of debugger, libraries, handset emulator, documentation, etc. (Maiyana, 2018). Android SDK is very important when building an android application in android studio. 


\section{H. License plate}

License plate is resident sign of vehicle and it is an evident of legitimate vehicle operational. In Indonesia license plate is contain code area, registration number, and duration of activation. License plate is attached in front side or rear side of the vehicle (Arief et al, 2018).

\section{System Usability Scale (SUS)}

System usability scale is scale that used to assessment of usability system. This method has been used by so many people to testing software, because it is easy to use and the result could be consideration. Another reason using this method is easy to understanding and easy to use, so that this method is popular to usability testing (Jiwa Permana, 2019).

This method has 10 questions and 5 answer options. The maximal score is 100 and minimal is 0 . The 10 questions can be seen in table 1 and the 5 answer questions can be seen in table 2 .

Table 1. List Question of SUS

\begin{tabular}{|c|c|}
\hline No. & Question \\
\hline 1 & I think that I would like to use this system frequently. \\
\hline 2 & I found the system unnecessarily complex. \\
\hline 3 & I thought the system was easy to use. \\
\hline 4 & $\begin{array}{l}\text { I think that I would need the support of a technical } \\
\text { person to be able to use this system. }\end{array}$ \\
\hline 5 & $\begin{array}{l}\text { I found the various functions in this system were well } \\
\text { integrated. }\end{array}$ \\
\hline 6 & $\begin{array}{l}\text { I thought there was too much inconsistency in this } \\
\text { system. }\end{array}$ \\
\hline 7 & $\begin{array}{l}\text { I would imagine that most people would learn to use } \\
\text { this system very quickly. }\end{array}$ \\
\hline 8 & I found the system very cumbersome to use. \\
\hline 9 & I felt very confident using the system. \\
\hline 10 & $\begin{array}{l}\text { I needed to learn a lot of things before I could get going } \\
\text { with this system. }\end{array}$ \\
\hline
\end{tabular}

Table 2. List Answer option of SUS

\begin{tabular}{|c|l|c|}
\hline No. & \multicolumn{1}{|c|}{ Option } & Score \\
\hline 1 & Strongly Disagree & 1 \\
\hline 2 & Disagree & 2 \\
\hline 3 & Half and half & 3 \\
\hline 4 & Agree & 4 \\
\hline 5 & Strongly Agree & 5 \\
\hline
\end{tabular}

After collecting data from respondents, data will be measure to find out the average score from all respondents. The average score will be conclude by SUS score to find out in which grade. SUS score can be seen in picture 1 .

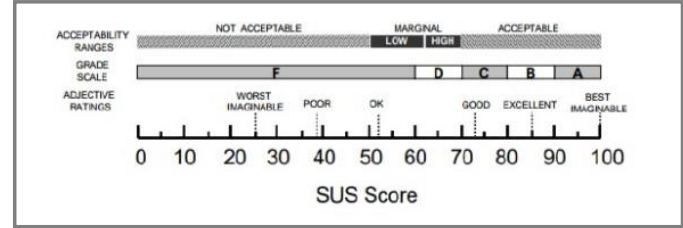

\section{Picture 1. SUS Score}

\section{RESEARCH METHODS}

\section{A. Research Time and Place}

This research conducted at Samarinda City especially in parking are of Agriculture Polytechnic of Samarinda. It takes duration from October 2019 January 2020. Includes making proposal, collecting data, application development, and reporting.

\section{B. Tools and Materials}

Hardware that used in development are as follows:

1. ASUS Laptop A455L (Intel Core i5-5200U, CPU $2.2 \mathrm{GHz}, \mathrm{RAM}$ 12GB DDR3L, 500GB HDD, 256GB SSD)

2. Android smartphone Realme 5 Pro (Android Pie 9.0, 48 MP Camera)

Software that used in development are as follows:

1. Android Studio

2. Android SDK

3. Java Development Kit

4. Library Mobile Vision API

\section{Research Procedure}

Research procedure of this paper is start from identification, literature study, designing system, building system, testing system, and if there is a bug fixing system is needed. Research procedure can be seen in picture 2 . This research procedure is shown as flow chart diagram.

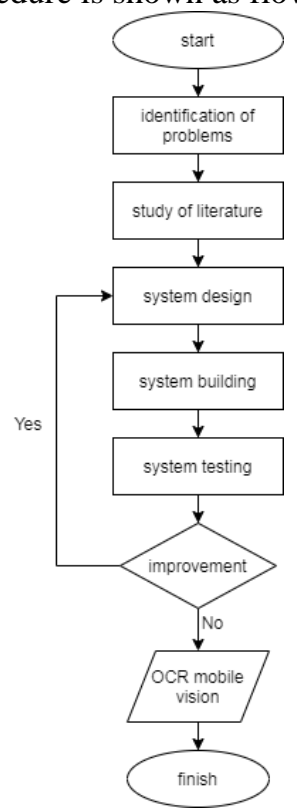

Picture 2. Research Procedure

Method that used in developing the system is Waterfall. This method can be seen in picture 3 . 


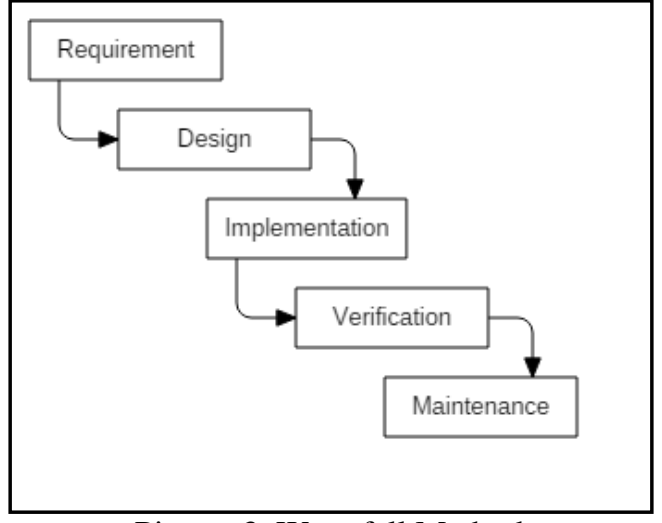

Picture 3. Waterfall Method

\section{System Design}

Designing User Interface (UI) is a process to create effective communication media between human and computer or mobile application. UI is connector between user and system (Susilo et al, 2018).

Picture 4 shows the mockup of first page of this application.

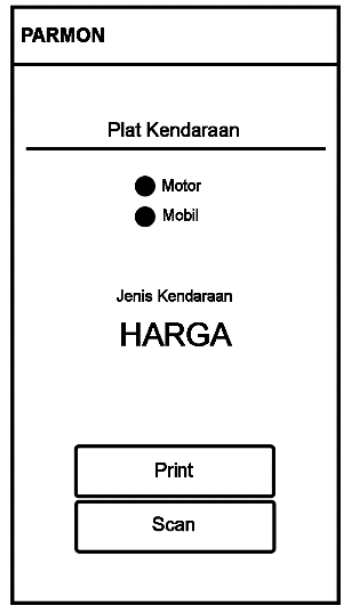

Picture 4. User Interface Home Design

Picture 5 shows the mockup of scan page of this application.

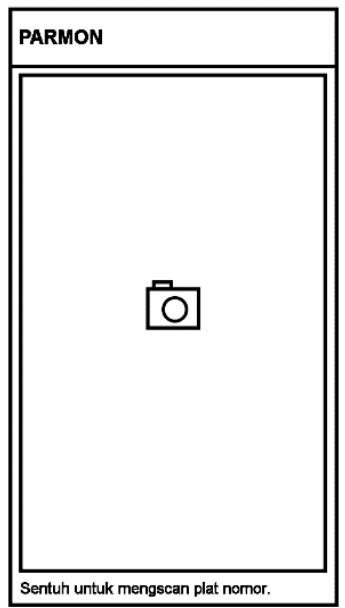

Picture 5. User Interface Scan Design
Picture 6 shows the mockup of scan page of this application.

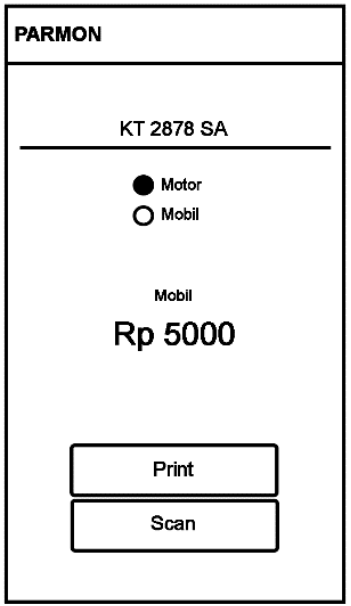

Picture 6. User Interface Result Design

\section{E. Analysis System}

1. Use Case Diagram

Use case diagram is model to behavior of information system. That used to know what is in information system (Sihotang, 2017). Use case diagram for this system can be seen in picture 7 .

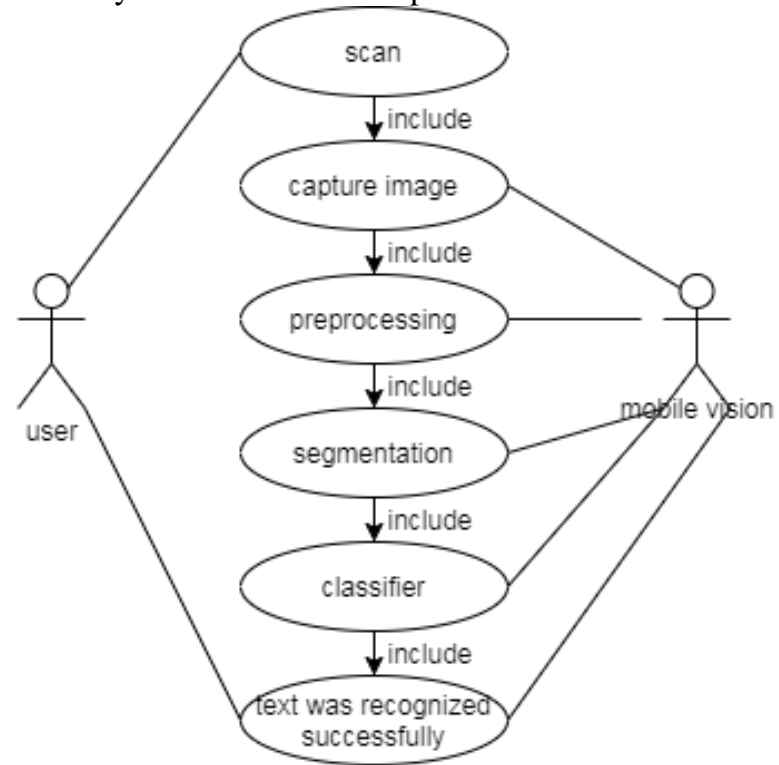

Picture 7. Use Case Diagram

\section{Activity Diagram}

Activity diagram is continuance of use case diagram, where activity diagram is show activities that user can do in system (Sukamto et al, 2016). Activity diagram for this system can be seen in picture 8 . 


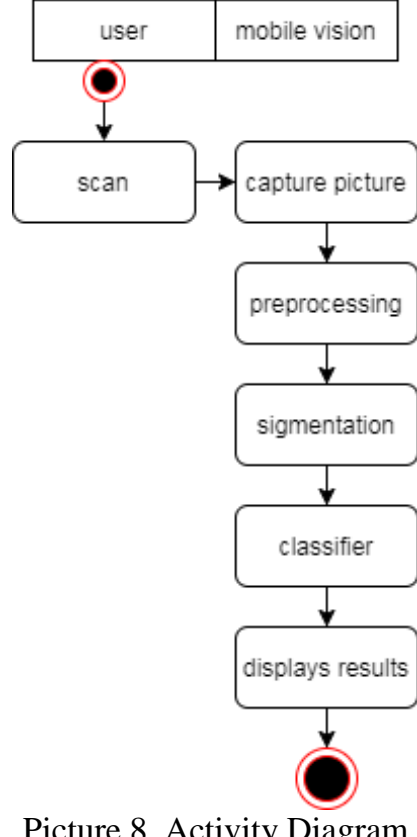

3. Sequence Diagram

Sequence diagram is an illustration that show how the system will give response back from user instruction (Sukamto et al., 2016). Sequence diagram for this system can be seen in picture 9 .

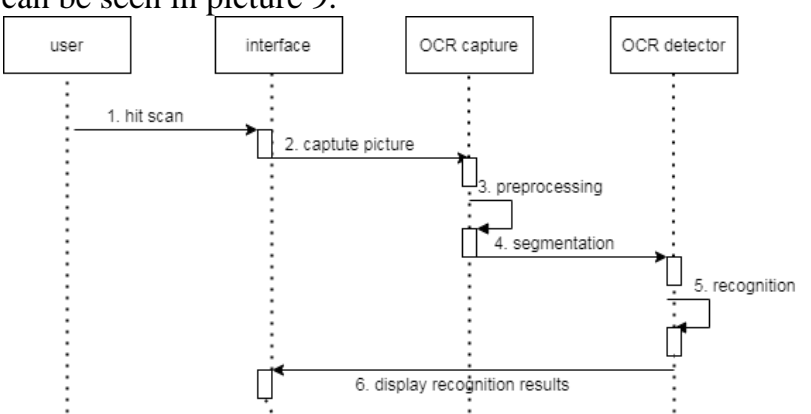

Picture 9. Sequence Diagram

\section{RESULT AND DISCUSSION}

A. Implementation Interface

1. First Page

Picture 10 is shows the main page display of the application that contain form to input license plate by scan, vehicle type, and print.

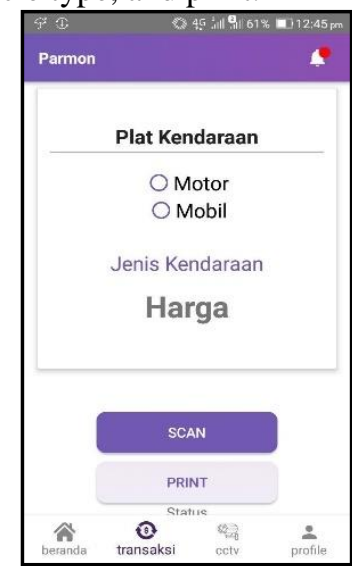

Picture 10. First Page Interface
2. Scan Page

Picture 10 is shows the second page of application that contain camera for scan the license plate.

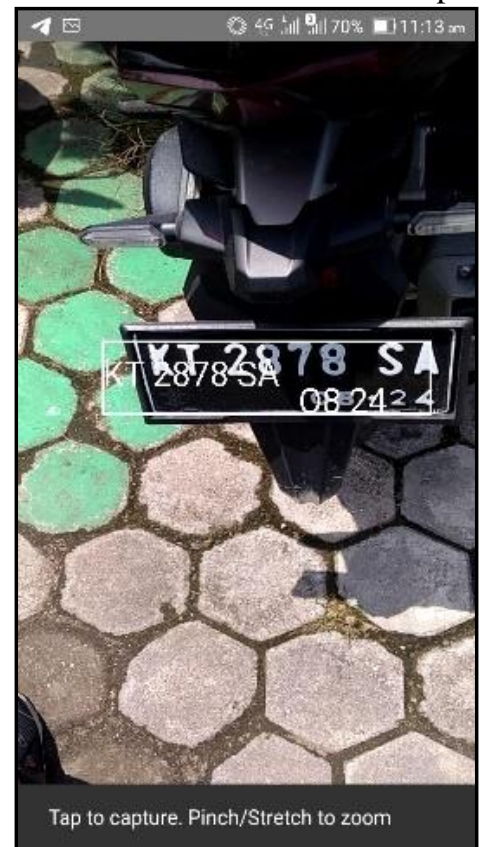

Picture 11. Scan Page Interface

3. Result Page

Picture 12 is shows the result page of application after scanning license plate. This page contain license plate that has recognized, the price of parking service depend on type of vehicle.

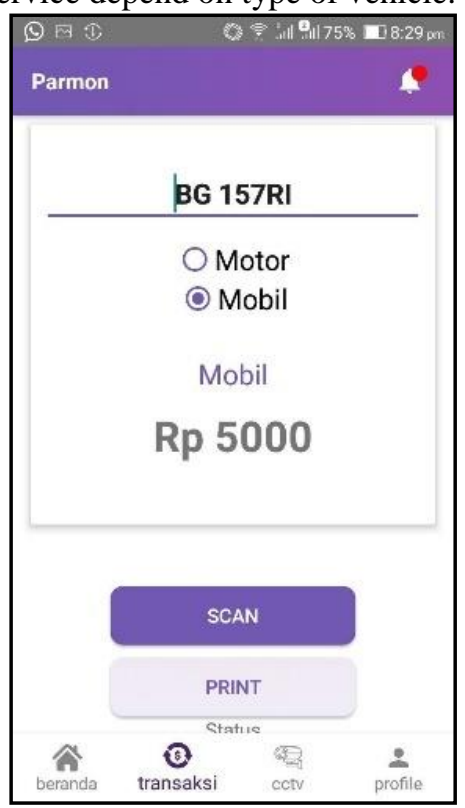

Picture 12. Scan Page Interface

4. Print Page

Picture 13 is shows the print page of application after scanning license plate. This page contain list of Bluetooth printer devices that connected to application for print parking ticket. 


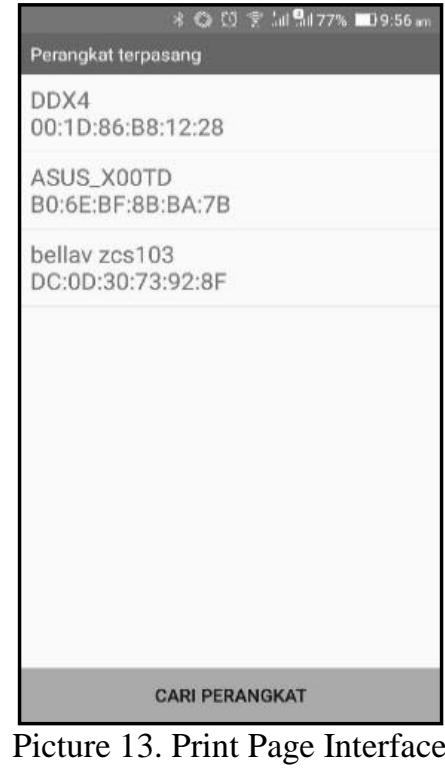

\section{B. Accuracy Testing}

Accuracy testing is conducted on purpose to know the accuracy of mobile vision. There are 50 data of license plate that have been collected and can be seen in table 3 .

Table 3. License plate Data

\begin{tabular}{|l|c|}
\hline License plate Type & Quantity \\
\hline Black License plate & 30 \\
\hline Yellow License plate & 10 \\
\hline Red License plate & 10 \\
\hline
\end{tabular}

From 50 data the mobile vision can recognize the license plate that correct and accurate is 35 data. There is no wrong recognizing of the character of text. Picture 14 is shows the sample of accurate data.

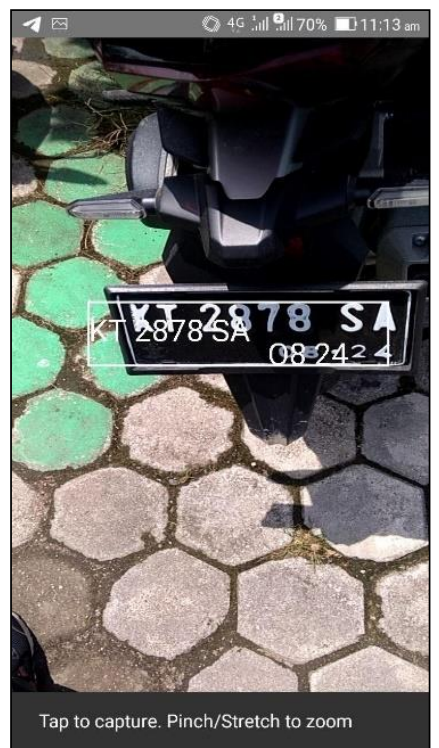

Picture 14. Sample Accurate Data
From 50 data the mobile vision can recognize the license plate that not correct and not accurate is 15 data. There is wrong when mobile vision recognizing the character because of the font is not clear. Like letter Q mostly recognize as letter $\mathrm{O}$, letter $\mathrm{O}$ mostly recognize as number 8 , number 4 sometimes recognize as letter $\mathrm{A}$, and number 6 sometimes recognize as number 8 . Picture 15 is shows the sample of accurate data.

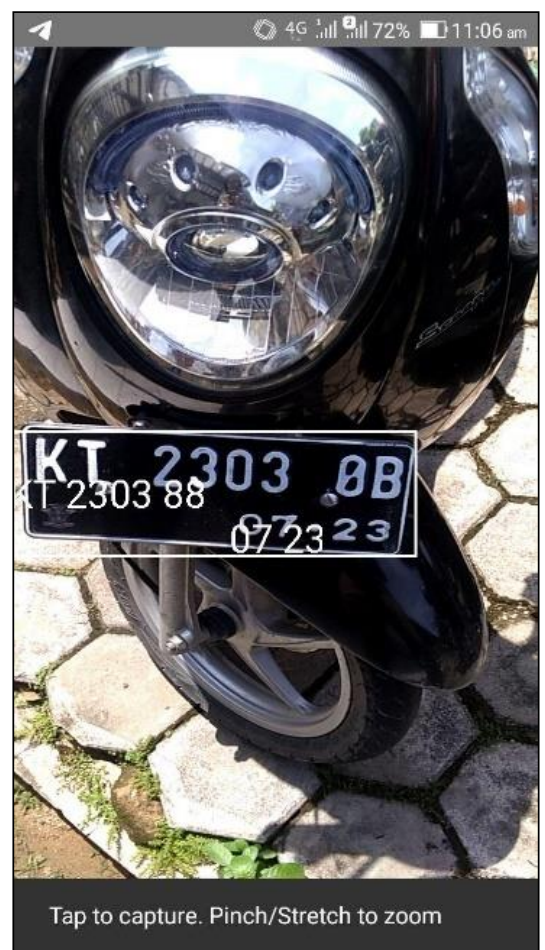

Picture 15. Sample Not Accurate Data

From the data that has been collected, the result of accuracy testing is shown in table 4 .

Table 4. Result of Accuracy Testing

\begin{tabular}{|l|c|c|c|}
\hline License plate Type & Quantity & $\begin{array}{c}\text { Data } \\
\text { Accurate }\end{array}$ & $\begin{array}{c}\text { Data Not } \\
\text { Accurate }\end{array}$ \\
\hline Black License plate & 30 & 20 & 10 \\
\hline Yellow License plate & 10 & 8 & 2 \\
\hline Red License plate & 10 & 7 & 3 \\
\hline Total & 50 & 35 & 15 \\
\hline
\end{tabular}

After got the result of accurate and not accurate data. The calculation to get percentage accuracy of mobile vision is doing by find the average (1)

$$
\begin{aligned}
\text { Accurate } & =(\text { Total Accurate / Total Data }) * 100 \% \\
& =(35 / 50) * 100 \% \\
& =70 \%
\end{aligned}
$$

Not Accurate $=($ Total Not Accurate/Total Data $) * 100 \%$ $=(15 / 50) * 100 \%$

$$
=30 \%
$$


From the result of calculation to find out the percentage of accuracy from 50 data. The accuracy of text recognition mobile vision API is $70 \%$.

\section{Specification Testing}

Specification testing is conducted on purpose to find out the minimum specification require from the smartphone so the user can use the application confidently. If the application running in smartphone that have specification below the minimum specification there will be lag and make user not confident (Dharma et al, 2015).

This testing is using 5 different type and specification smartphone and can be seen in table 5 .

Table 5. List Smartphone

\begin{tabular}{|l|c|c|}
\hline Smartphone & Camera & Android \\
\hline Realme 5 Pro & 48 MP 2160p & 10 \\
\hline Asus Zenfone 4 Max Pro & 16 MP 1080p & 8.0 \\
\hline Oppo A71 (2018) & 13 MP 1080p & 7.1 .1 \\
\hline Redmi 5 Plus & 12 MP 2160p & 7.1 .2 \\
\hline Asus Zenfone 4 Max & 13 MP 1080p & 8.0 \\
\hline
\end{tabular}

This 5 smartphone tested by maximum distance when using mobile vision to scan license plate with and without camera zoom. The result can be seen in table 6 .

Table 6. Result Maximum Distance Testing

\begin{tabular}{|l|c|c|}
\hline Smartphone & Max Distance & $\begin{array}{c}\text { Max } \\
\text { Distance } \\
\text { with Zoom }\end{array}$ \\
\hline Realme 5 Pro & \pm 5 Meter & \pm 9 Meter \\
\hline Asus Zenfone 4 Max Pro & \pm 4 Meter & \pm 6 Meter \\
\hline Oppo A71 (2018) & $\pm 2,5$ Meter & $\pm 4,5$ Meter \\
\hline Redmi 5 Plus & \pm 3 Meter & \pm 5 Meter \\
\hline Asus Zenfone 4 Max & \pm 4 Meter & \pm 6 Meter \\
\hline
\end{tabular}

Based on result of maximum distance testing the quality of smartphone camera like number of megapixel is giving effect into maximum distance when scan using mobile vision. The higher megapixel, more detail and clear the mobile vision can recognize.

With detail image then mobile can recognize easily. Can be seen the smartphone with 12 megapixel camera and 13 megapixel camera there are some differences maximum distance. Contrast with smartphone with 16 megapixel camera and 48 megapixel camera that have much differences maximum distance. Picture 16 is sample from farthest smartphone is Realme 5 Pro with 48 megapixels camera with zoom.

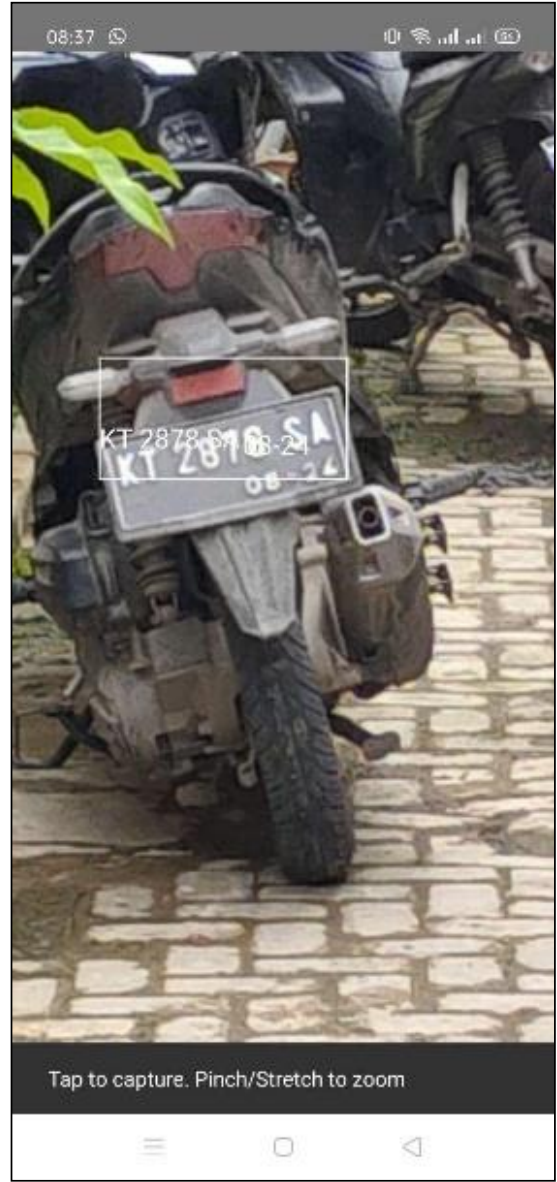

Picture 16. Sample Farthest Smartphone Scan

Based on result the minimum specification requirement to use this application can be seen in table 7 .

Table 7. Minimum Specification Requirement

\begin{tabular}{|l|c|}
\hline Operation System & Android \\
\hline Version & 5.0 Lollipop \\
\hline Camera & $12 \mathrm{MP}$ \\
\hline
\end{tabular}

And the recommended specification requirement to use this application can be seen in table 8 .

Table 8. Recommended Specification Requirement

\begin{tabular}{|l|c|}
\hline Operation System & Android \\
\hline Version & $9.0 \mathrm{Pie}$ \\
\hline Camera & $48 \mathrm{MP}$ \\
\hline
\end{tabular}

With this specification testing, the user could know the exact smartphone specification that can run the application smooth without lagging.

\section{Respondent Testing}

User Interface testing is conducted with respondent and using SUS questionnaire. The result of respondent testing can be seen in table 9 . 
Table 9. SUS Score Result

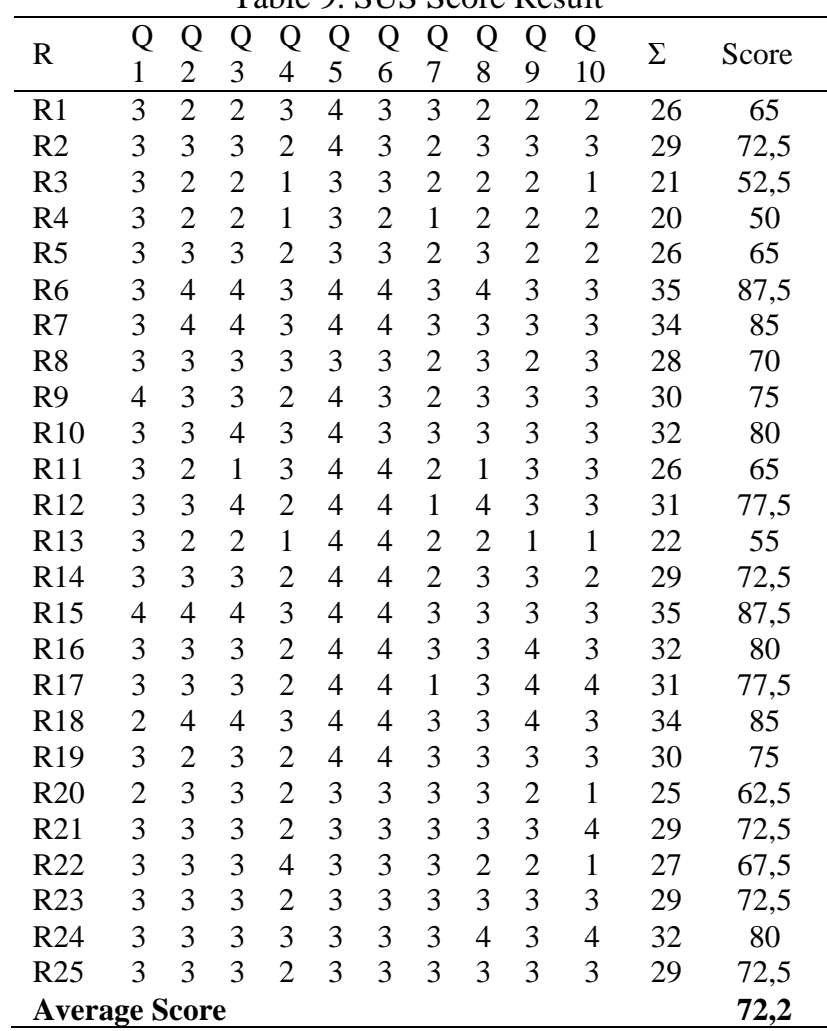

After calculation from respondent score data then the average score got 72,2 . This is prove that this system can be accepted by respondent because the average score is above the average standard and got grade scale $\mathrm{C}$ rating good.

\section{E. Black box Testing}

In building an application the application testing is needed to check the application running well. This testing is giving input and testing on functional program (Nurudin et al, 2019)

This testing done thoroughly to find out that this application is running well. The black box testing can be seen in table 10 .

Table 10. Black box Testing

\begin{tabular}{|c|c|c|}
\hline No. & Expected Result & Result \\
\hline 1. & Show first page & Work \\
\hline 2. & Show scan page & Work \\
\hline 3. & $\begin{array}{l}\text { Scanned text that touched and } \\
\text { sent to next page }\end{array}$ & Work \\
\hline 4. & $\begin{array}{l}\text { Show the page result after text } \\
\text { scanned }\end{array}$ & Work \\
\hline 5. & $\begin{array}{l}\text { Show name, type, and price } \\
\text { based on vehicle type that } \\
\text { choose }\end{array}$ & Work \\
\hline 6. & $\begin{array}{l}\text { Show printer choice and } \\
\text { printing }\end{array}$ & Work \\
\hline
\end{tabular}

\section{CONCLUSION}

Result of research License plate Recognition Integrated with Android and Mobile Vision the final conclusion is mobile vision could be implemented in android application that build with android studio. The accuracy of mobile vision based on 50 data accuracy testing is $70 \%$ on license plate that has good and clear text. Based on result of respondent testing using SUS, the advice is to improve the user interface that more interesting and make user easy to use. Adding some feature also have to develop like button to activate flash, so if the area is too dark the user can use flash.

\section{REFERENCES}

Arief, J., Utaminingrum, F., \& Sari, Y. A. (2018). Penentuan Jumlah Karakter pada Plat Nomor Kendaraan dengan menggunakan Selective Ratio Bounding Box. 2(1), 256-262.

Dharma, N. S., Sudarma, M., \& Suyadnya, M. A. (2015). Rancang Bangun Aplikasi Gamelan Gender. 2(2), 18-23.

Hartanto, S., Sugiharto, A., \& Endah, S. N. (2015). Optical Character Recognition Menggunakan Algoritma Template Matching Correlation. Jurnal Masyarakat Informatika, 5(9), 1-12. https://doi.org/10.14710/jmasif.5.9.1-12

Ibnutama, K., Panjaitan, Z., \& Ginting, E. F. (2019). Modifikasi Metode Template Matching pada OCR Untuk Meningkatkan Akurasi Deteksi Plat Nomor Kendaraan. Jurnal Teknologi Sistem Informasi Dan Sistem Komputer TGD, 2(2), 21-29.

Jiwa Permana, A. A. (2019). Usability Testing Pada Website E-Commerce Menggunakan Metode System Usability Scale (SUS) (Studi Kasus : UMKMBULELENG.Com). JST (Jurnal Sains Dan Teknologi), 8(2), 149. https://doi.org/10.23887/jstundiksha.v8i2.22858

Kusumawati, K., \& Cahyadi, D. W. (2017). Penerapan Teknologi Optical Character Recognition Untuk Mendeteksi Plat Nomor Kendaraan. Prosiding Seminar Nasional Inovasi Teknologi, 12-20.

Maiyana, E. (2018). Pemanfaatan Android Dalam Perancangan Aplikasi Kumpulan Doa. 1, 54-67.

Mansyur, Y. (2018). Optical Character Recognition Untuk Deteksi Pelat Mobil Dan Motor Kendaraan Pada Kampus Teknik Gowa.

Mardiansyah, D. (2017). Pemanfaatan Library OpenCV dan Tesseract Untuk Pengenalan Plat Nomor Mobil Format Negara Indonesia.

Ming, C. Y. (2018). Mobile Application For Interactive Digital Business Card. (May).

Nurudin, M., Jayanti, W., Saputro, R. D., Saputra, M. P., \& Yulianti, Y. (2019). Pengujian Black Box pada Aplikasi Penjualan Berbasis Web Menggunakan Teknik Boundary Value Analysis. Jurnal Informatika Universitas Pamulang, 4(4), 143. https://doi.org/10.32493/informatika.v4i4.3841 
Sihotang, H. T. (2017). Pembuatan Aplikasi E-Learning Pada Smk Swasta. Jurnal Mantik Penusa, 1(2), 7075.

Sukamto, T. S., Nugroho, L. E., \& Winarno, W. W. (2016). Desain Sistem Informasi Akreditasi Program Studi Berbasis Website di Indonesia. Seminar Nasional Aplikasi Teknologi Informasi (SNATi) Agustus, 1907-5022.

Susilo, E., Wijaya, F. D., \& Hartanto, R. (2018). Perancangan dan Evaluasi User Interface Aplikasi Smart Grid Berbasis Mobile Application. Jurnal Nasional Teknik Elektro Dan Teknologi Informasi (JNTETI), $\quad 7(2), \quad 150-157$. https://doi.org/10.22146/jnteti.v7i2.416

Utama, S. W., \& Kusumawardhani, A. (2018). Aplikasi Pendeteksi Plat Nomor Negara Indonesia Menggunakan OpenCV dan Tesseract OCR pada Android Studio. (December), 1-6. 